\title{
Reduction of the Livestock Ammonia Emission under the Changing Temperature during the Initial Manure Nitrogen Biomineralization
}

\author{
Rolandas Bleizgys, ${ }^{1}$ Indrè Bagdoniené, ${ }^{1}$ and Ligita Baležentien ${ }^{2}$ \\ ${ }^{1}$ Institute of Energy and Biotechnology Engineering, Aleksandras Stulginskis University, Kaunas distr. 53361 Akademija, Lithuania \\ ${ }^{2}$ Institute of Ecology and Environment, Aleksandras Stulginskis University, Kaunas distr. 53361 Akademija, Lithuania
}

Correspondence should be addressed to Ligita Baležentiené; ligita.balezentiene@asu.lt

Received 11 September 2013; Accepted 10 October 2013

Academic Editors: G.-C. Fang and G. O. Thomas

Copyright (C) 2013 Rolandas Bleizgys et al. This is an open access article distributed under the Creative Commons Attribution License, which permits unrestricted use, distribution, and reproduction in any medium, provided the original work is properly cited.

\begin{abstract}
Experimental data were applied for the modelling optimal cowshed temperature environment in laboratory test bench by a mass-flow method. The principal factor affecting exponent growth of ammonia emission was increasing air and manure surface temperature. With the manure temperature increasing from $4^{\circ} \mathrm{C}$ to $30^{\circ} \mathrm{C}$, growth in the ammonia emission grew fourfold, that is, from 102 to $430 \mathrm{mg} \mathrm{m}^{-2} \mathrm{~h}^{-1}$. Especial risk emerges when temperature exceeds $20^{\circ} \mathrm{C}$ : an increase in temperature of $1^{\circ} \mathrm{C}$ contributes to the intensity of ammonia emission by $17 \mathrm{mg} \mathrm{m}^{-2} \mathrm{~h}^{-1}$. The temperatures of air and manure surface as well as those of its layers are important when analysing emission processes from manure. Indeed, it affects the processes occurring on the manure surface, namely, dehydration and crust formation. To reduce ammonia emission from cowshed, it is important to optimize the inner temperature control and to manage air circulation, especially at higher temperatures, preventing the warm ambient air from blowing direct to manure. Decrease in mean annual temperature of $1^{\circ} \mathrm{C}$ would reduce the annual ammonia emission by some $5.0 \%$. The air temperature range varied between $-15^{\circ} \mathrm{C}$ and $30^{\circ} \mathrm{C}$ in barns. The highest mean annual temperature $\left(14.6^{\circ} \mathrm{C}\right)$ and ammonia emission $\left(218 \mathrm{mg} \mathrm{m}^{-2} \mathrm{~h}^{-1}\right)$ were observed in the semideep cowshed.
\end{abstract}

\section{Introduction}

Ammonia $\left(\mathrm{NH}_{3}\right)$ emissions compose significant environmental pollution, which is related to agriculture, particularly with husbandry [1]. The highest $\mathrm{NH}_{3}$ emissions of $75 \%$ derived from livestock production in dependence of livestock housing buildings, manure storage, and so forth [2].

Construction of the uninsulated (field climate) barns constitutes the principal livestock barn development trend in Lithuania. Furthermore, the conventional insulated barns are reconstructed to deep bedding/litter and box types, featuring uninsulated outer walls or only roof thermally insulated leading to the more natural cow housing conditions. Increasing productivity per cow and also altered perception of their housing conditions had a significant impact on such cowshed development trends. The recommended temperature has generally decreased. Epinatjeff [3] found out that the preferred temperature should range in between $-10^{\circ} \mathrm{C}$ and $+5^{\circ} \mathrm{C}$ for the cow which produces 20 and more $\mathrm{kg}$ of milk per day. Nonetheless, in order to maintain continuous manure removal, the barn temperature should not fall below $-18^{\circ} \mathrm{C}$ [4]. Uninsulated barn type is well acknowledged across many countries. Thus, the intensive construction of suchlike barns was initiated in 1980s Western Europe, in 1990s in Scandinavian countries, Estonia and Lithuania $[5,6]$.

The modernization of the livestock buildings in Lithuania often involves some issues related to ambient air pollution: application of littered or unlittered livestock keeping technology; barn ventilation intensity; temperature maintained in the barn. The lack of reliable data on ambient air ammonia pollution from newtype cowsheds complicates the evaluation of these new technologies in terms of environmental protection. Thus, livestock is an important source of air pollution, which contributes to some $90 \%$ of the global ammonia environmental emission [7]. In agriculture sector, the most significant share of ammonia (50\%) is emitted 
from cattle, $20-22 \%$ from pig, $7-21 \%$ from poultry, 9-18\% from mineral fertilizing, and only 3-9\% from horse, sheep, and other animals. However ammonia emission from barns composed $37-50 \%$ of total livestock emission $[8,9]$. In order to reduce these emissions, it is necessary to apply sustainable technologies there. Though considerable investigations were carried out, the determination of the emissions from the open cattle barns still remained a problematic issue[10, 11]. Numerous researchers identified many methodological problems related to analysis of the gas emissions in open cattle barns. In addition, it is difficult to determine the accurate intensity of the ventilation in open barns. Therefore many studies attempted to improve research methods continuous measurements $[12,13]$. Thereafter, intermittent measurement method was proposed to shorten the investigation period. Primarily, it is necessary to determine the annually changing microclimatic factors of a barn, for example, outdoor and barn temperature, ventilation intensity which varies throughout the year and affects the emission intensity, and select periods of measurements. Having measured the emission intensity, the significant annual emission from a barn can be forecasted $[14,15]$. Fast and accurate determination of the gas concentration is also aggravated by the high ammonia concentration gradients within $0.1 \mathrm{~m}$ height above the manure layer [16]. Therefore, in order to obtain consistent data in emissions from manure, application of precise description of processes affecting the $\mathrm{NH}_{3}$ emission intensity is essential, notwithstanding permanent change of multiple factors (the changing air velocity, turbulence, and temperature) causes the ammonia emission to vary significantly affecting emission [2, 17]. Ammonia emission changes also significantly depended on the crust formation on manure surface. Crust formation is substantially influenced by the straw and dry matter content in the manure as well as environmental climatic conditions [18]. Besides, ammonia emission from cows is influenced by feeding during lactation [19]. When analysing the emission processes, the investigations are often limited to one of the most important and influencing factors affecting the emission intensity. The temperature can be treated as a key factor due to its higher positive impact on ammonia emission if compared to that frequency of manure removal, floor condition and cleaning, feeding cow activity. Thereafter, daily and annual ammonia emissions from manure vary unevenly. When temperature rises from $2^{\circ} \mathrm{C}$ to $20^{\circ} \mathrm{C}$ in the barn, the emission of ammonia pollution increases from 10 to $30 \mathrm{~g}$ per cow place (cow producing $1000 \mathrm{~W}$ total heat) per day [20]. Consequently, temperature decrease presents a good and effective way to reduce $\mathrm{NH}_{3}$ emissions. Moreover, the application of chemical agents is also proposed as a mean to reduce emissions from manure at high temperatures [21]. It is commonly agreed that the high barn temperature might increase the temperature of both surface and manure and thus lead to increased emissions [10, 21]. Emission increases considerably when the weather is warming up and tending to be drier [17]. Nonetheless, the researchers determined that the direct effects of temperature on ammonia emissions differ significantly. Ammonia emission remains of about two times lower at manure temperature of some $15^{\circ} \mathrm{C}$ if compared to that at $25^{\circ} \mathrm{C}[22]$. Exponential increase of ammonia emission close to three times, as well as increasing the $\mathrm{CO}_{2}$ and $\mathrm{CH}_{4}$ emission, was observed at the temperature increasing from $5^{\circ} \mathrm{C}$ to $35^{\circ} \mathrm{C}$ in the test chambers [23]. Ammonia emission varied from 11 to $88 \mathrm{~g}$ per cow per day when air temperature changed from $2.3^{\circ} \mathrm{C}$ to $22.4^{\circ} \mathrm{C}$ in naturally ventilated cowshed $[24,25]$. Temperature frequently remains the main reason for lower quantities of gas pollutant which are emitted from the open cowsheds than those from the insulated barn. According to Teye [13], a cold barn featured temperature fluctuates from $-7^{\circ} \mathrm{C}$ to $+24^{\circ} \mathrm{C}$, and ammonia emission ranges from $7 \mathrm{~g}$ to $35 \mathrm{~g}$ per day per cow. Different scientific studies are carried out generally at different temperatures, temperature ranges, and different chemical composition of manure; thereafter the results are rather different; for example, an increase in temperature of $1^{\circ} \mathrm{C}$ results in ammonia emission increase of $10 \%$ to $39 \%$. Most of the researches are carried out on ammonia by analysing emissions from manure at various temperatures.

In order to find the optimal inner temperature in the cowsheds which ensures that the animals are not harmed and to relate it to the emissions from naturally ventilated open cowsheds, the research focused on (i) gathering the reliable data on ambient temperature and ammonia emission process across different cowsheds and (ii) analysing the effects of the temperature gradient on the ammonia emissions.

\section{Materials and Methods}

2.1. Microclimate Measurements in Cowsheds. Microclimate pilot studies were carried out on the cowsheds of the three types prevailing in Lithuania: semideep insulated in the Training Farm of Aleksandras Stulginskis university (Kaunas distr.), cold in the cooperative Lumpenu̧ rambynas (Lumpenai, Šilute distr.), and box partially thermally insulated (insulated only barn roof) in the company Bernatoniai (Bernatonys, Kaunas distr.). A semideep barn is often a result of the reconstruction of the old small tied barn. Some 140 cows are kept in the semi deep barn, which features its walls being built of concrete blocks and floor (ceilings) insulated with a thick layer of straw. Barn is equipped with the channel ventilation system. The surface of cow places is littered with straw (four rolls of $350 \mathrm{~kg}$ of straw litter per day). The mobile manure technology is applied once per month. The box cold barn contains 220 and has uninsulated wall and roof. Its roof is only capped with tin plate, the average wall, and roof heat transmission coefficient which equals $4.5 \mathrm{~W}\left(\mathrm{~m}^{2} \mathrm{~K}\right)^{-1}$. The cows are kept in shallow boxes, floors of which are covered with rubber mats $30 \mathrm{~mm}$ in thickness. Walking tracks are covered in concrete, whereas the manure is removed by a scraper transporter. The cowshed is equipped with a nonchannel, ridge-slit ventilation system. The air inflows through wall slots covered with grids and outflow are removed through the ridge holes. Air circulation was controlled by lifting the securer blind and changing width of wall slots. The average wall and roof heat transmission coefficients were $3.3 \mathrm{~W}\left(\mathrm{~m}^{2} \mathrm{~K}\right)^{-1}$ and $0.45 \mathrm{~W}\left(\mathrm{~m}^{2} \mathrm{~K}\right)^{-1}$, respectively, in the partially insulated (insulated roof only) box-type cowshed of 230 boxes. The fresh air inflows occurred through the securer 
adjustable onwall openings, whereas the contaminated one is removed through a regulated ridge slots. The no-littered technology is applied in the cowshed. The rubber covers are laid in the rest boxes. The manure tracks were covered with grid. $1.2 \mathrm{~m}$ deepness manure circulation channels were installed under the cows walking tracks.

The key microclimate variables (temperature and ammonia concentration) were measured in the cowsheds at different seasons of the year. Air temperature was recorded every hour with a computer-controlled temperature and humidity meter-storage device COX TRACER Almemo 2590-9. Preset temperature measuring range recorded was from $-30^{\circ} \mathrm{C}$ to $40^{\circ} \mathrm{C}\left( \pm 0.3^{\circ}\right)$ with 8 sensors, two outer and six inner at various locations. Ammonia gas concentration in the cowsheds was measured using air sampling system ECOM which facilitated air sampling and transportation to the laboratory, whereas the $\mathrm{NH}_{3}$ concentration was measured by the analyser GME700.

\subsection{Research in Laboratory Experimental Bench. Having} defined the methodological problems of gases analysis in the open naturally ventilated cowsheds, an experimental bench (Figure 1) for modelling of the emission processes from manure under varying ambient temperature was designed and produced. The impact temperature on ammonia emission intensity from manure was determined in the test bench by modelling potential temperature in cowsheds. The fresh barn manure (3) was placed into the chamber (5) in a layer of 0.12 to $0.15 \mathrm{~m}$. The manure chamber was placed on the thermostat (1), which heats the manure from the bottom. Two ducts entered into the chamber: the warmed air from the climatic chamber Memmert ICP 600 (21) through duct (7) was imputed to the manure chamber (5) and was pumped out through the second duct (9) of $50 \mathrm{~mm}$ diameter and $1500 \mathrm{~mm}$ length. The input duct length of the air sampling probe was $500 \mathrm{~mm}$, that is, 10 times larger than its diameter. Such duct length ensured a laminar air flow.

Air flow velocity in the duct and chamber ventilation intensity was adjusted by using the frequency converter to adjust the fan (13) rotation and thus valve (12) to change the duct diameter area. Air velocity was measured in duct (9) by anemometer OMEGAFLO HH-F615 M and was converted to air flow intensity. The temperature and humidity of the outflow-inflow air of the chamber were measured by the temperature and humidity sensors (8) of the system ALMEMO 2590-9 (14). Gas emission intensity from the manure was measured by applying the mass flow method. The emission intensity $(E)$ was calculated into account, the chamber ventilation intensity $G\left(\mathrm{~m}^{3} \mathrm{~h}^{-1}\right)$, gas concentration in the outflow $\left(\mathrm{Ce}, \mathrm{mg} \mathrm{m}^{-3}\right.$ ), and gas concentration in the inflow air (Co),

$$
E=\left(C_{o}-C_{e}\right) G .
$$

The ammonia concentration was measured by the means of the gas analyzer GME700. Air samples from the ducts (9 and 7) were taken by probe (10) and through heated hose (20) supplied to the gas analyser (17). The air was supplied to the analyser continuously by pump (19) with a capacity of $61 \mathrm{~min}^{-1}$. To prevent the condensation of the air, it was warmed to $150^{\circ} \mathrm{C}$ in intestine (20) and electrically heated valve (18). The ammonia gas analyser GME700 determined the gas concentration in the air by the laser spectroscopy. Ammonia concentration was measured continuously and recorded every $1 \mathrm{~min}$

The temperatures of manure and its surface were measured by employing thermocouples (4) with a wire diameter of $0.1 \mathrm{~mm}$. Three thermocouples were laid on the manure surface and sensors of the other remaining thermocouples were arranged in vertical straight line at various manure depths. Temperature measurements were recorded by ALMEMO 2590-9 with a microprocessor for data processing and logger system. The sensors were connected to device ALMEMO featuring 9 inputs (ZA9020-FS) suitable for copper-constantan thermocouple. The fresh cattle manure of the varying moisture was assessed. The mixed and homogenised manure from the barn was taken in 20 litre buckets, which were placed for 24 hours in climate chambers with different temperatures: $4.2^{\circ} \mathrm{C}, 13.1^{\circ} \mathrm{C}, 24.5^{\circ} \mathrm{C}$, and $35.6^{\circ} \mathrm{C}$. Then manure has been spilled from the bucket in $0.12 \mathrm{~m}$ thickness layer in the bench chamber and stirred and the ammonia emission intensity was measured. During testing, temperature of supplied $3.26 \pm$ $0.21 \mathrm{~m}^{3} \mathrm{~h}^{-1}$ air flow to the manure chamber was $18.6 \pm 0.4^{\circ} \mathrm{C}$, while manure from the bottom has not been heated. These emission tests lasted $70 \mathrm{~min}$; 2 tests were performed with manure of different content of dry matter (DM): $11.84 \pm$ $0.12 \%$, and $8.62 \pm 0.09 \%$.

2.3. $\mathrm{NH}_{3}$ Emission of Heated Manure. In order to determine the detailed influence of temperature on ammonia emissions from the manure $(12.45 \pm 0.11 \% \mathrm{DM})$, the manure chamber (5) was heated $\left(45^{\circ} \mathrm{C}\right)$ from the bottom by the thermostat (1) generating temperature gradient in the vertical layers of the manure. The chamber temperature was constant at $20.6 \pm 0.3^{\circ} \mathrm{C}$. To determine temperature effect on ammonia emissions, the inflow air was heated by $6-7^{\circ} \mathrm{C}$ periodically every 20 hours. The test lasted 120 hours.

2.4. Statistical Analysis. The confidence intervals of the estimates were obtained by employing one-way analysis of variance (by ANOVA). The least significant differences between treatment means were determined using Fisher's least significant differences. Standard error (SE) has been calculated at a level of statistical significance $P<0.05$.

\section{Results and Discussion}

3.1. Temperature Variation in Different Cowsheds. In order to meet the cowsheds development trends, the research was performed in the most common cowshed type in Lithuania. Microclimate tests were performed during various seasons in three cowshed types: semideep, cold box, and box partially thermally insulated (insulated roof only). Animal keeping technology, the design of the construction, types and quantities of accumulated manure, and other environment factors varied across the cowsheds. Thereafter, they were specific with different inner temperature, one of the main 


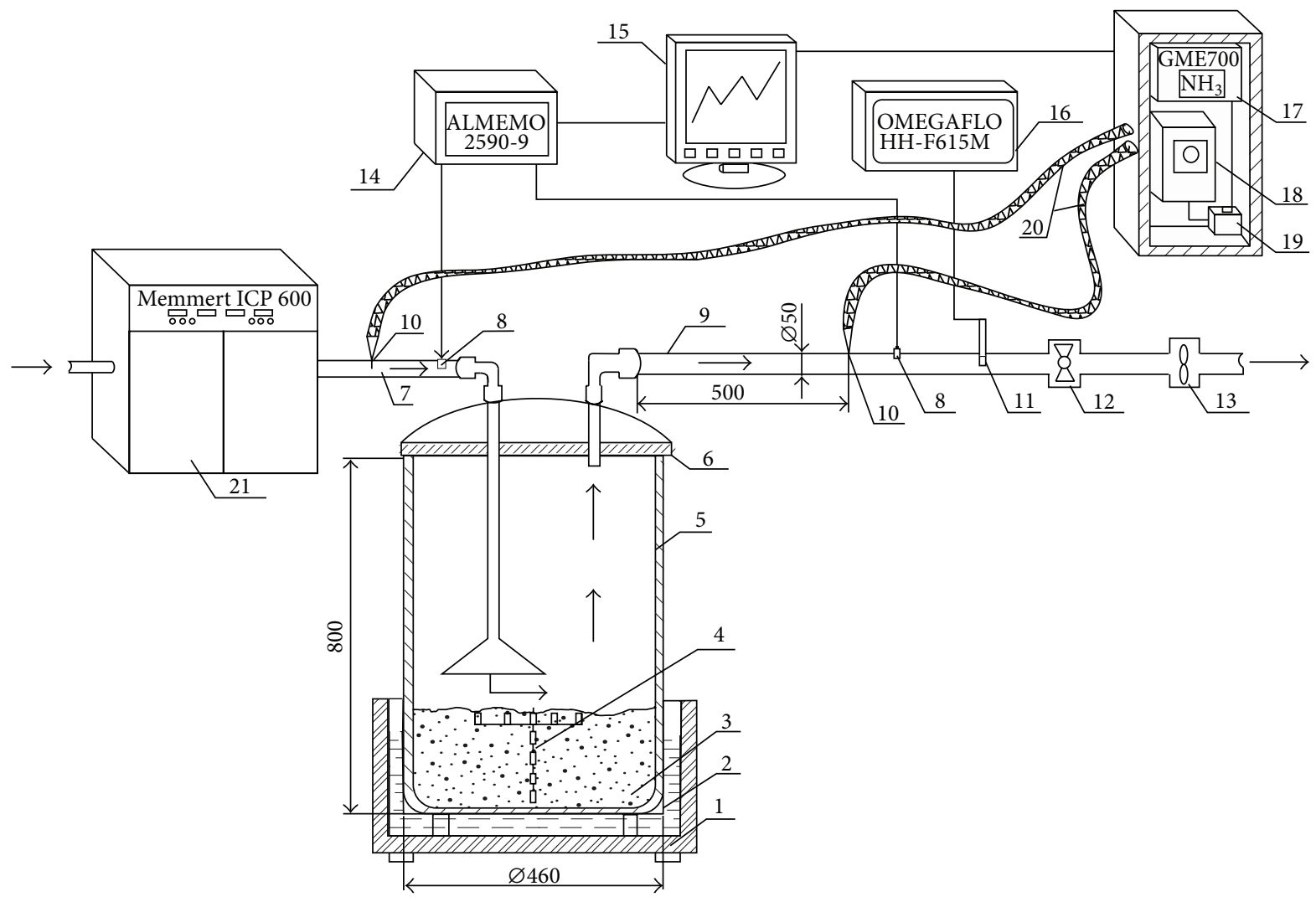

FIGURE 1: A test bench for modelling the gas emissions from manure: 1: thermostat, 2: water, 3: emission source-manure, 4: thermistor, 5: tight/close manure chamber (100 L capacity), 6: cover, 7: air supply duct, 8: the temperature and humidity sensors, 9: the outflow air duct, 10: air sampling probe, 11: thermoanemometer sensor, 12: valve, 13: a fan with frequency converter, 14: meter-logger ALMEMO 2590-9; 15: PC (program AMR), 16: anemometer OMEGAFLO HH-F615 M, 17: laser gas analyser GME700 18: electrically heated three-channel valves; 19: diaphragm air Pump, 20: heated air hose, 21: climatic camera Memmert.

features determining their functionality, affecting microclimate and gas emission from manure in cold cowsheds. During microclimate trials, the outer temperature ranged in between $-21.5^{\circ} \mathrm{C}$ and $32.0^{\circ} \mathrm{C}$ (Figure 2). Nonetheless, the inner temperature differed considerably: fell to $-15.2^{\circ} \mathrm{C}$ and only $1.8^{\circ} \mathrm{C}$ in cold and semideep cowsheds, respectively. The highest temperature of $29.4^{\circ} \mathrm{C}$ was observed in the cold box cowshed indeed. Throughout the year, semideep barn remained the warmest. Specifically, average annual temperature of $14.6^{\circ} \mathrm{C}$ was observed there, whereas slightly lower mean temperatures of $11.9^{\circ} \mathrm{C}$ and $11.2^{\circ} \mathrm{C}$ were observed in cold and partially insulated boxes, respectively.

These data were applied to estimate the regression equations relating air temperature in different cowsheds to the outer temperature (Table 1). Correlation coefficient $(r=0.9)$ shows a strong positive correlation between outer and inner temperatures of different cowsheds.

Different ambient temperature resulted in a varying ammonia concentration across various cowsheds during different seasons. When temperatures fall below $0^{\circ} \mathrm{C}$, ammonia was not found in cold box cowshed. It was determined that the warming weather and rising inner temperature increased ammonia concentration in barn. According to Zhang et al. [20], the warm and moist conditions not only promoted the

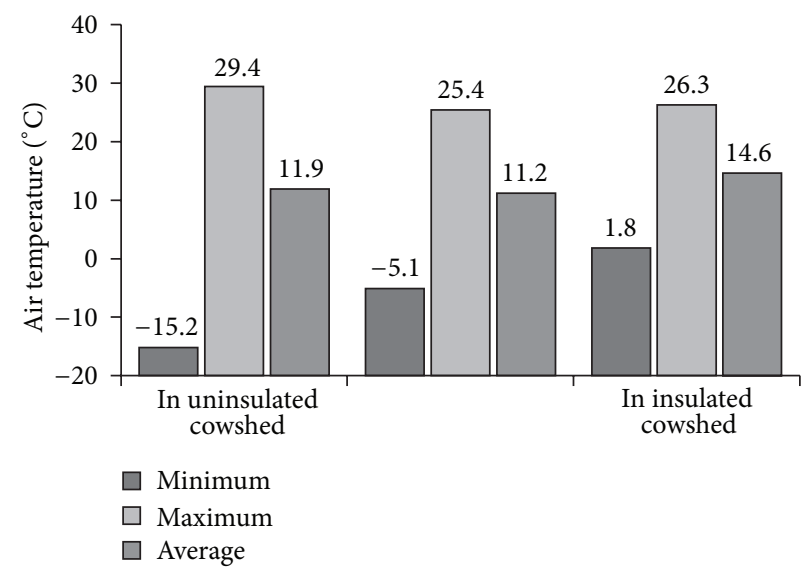

FIGURE 2: Inner temperature in different cowsheds in Lithuania $(P<$ $0.05)$.

spread of disease but also facilitated favourable conditions for ammonification bacteria activity and, thus, for ammonia emissions from manure. When temperature rose above $20^{\circ} \mathrm{C}$ in the barn, ammonia concentration increased to $8.5-9.0 \mathrm{ppm}$ and from 13.5 to $14.8 \mathrm{ppm}$ in semi deep barn due to lack of barn ventilation. 
TABLE 1: Correlation between inner, $t_{c}$, and outer, $t_{o}$, temperatures in different cowsheds.

\begin{tabular}{lc}
\hline Cowshed type & \multicolumn{1}{c}{ Regression } \\
\hline Cold box & $t_{c}=0.865 t_{o}+5.17 ; R^{2}=0,980(P<0.05)$ \\
Box partially thermally & $t_{c}=0.5039 t_{o}+7.03 ; R^{2}=0.934$ \\
insulated & $t_{c}=0.4462 t_{o}+11.78 ; R^{2}=0.822$ \\
Semi deep insulated &
\end{tabular}

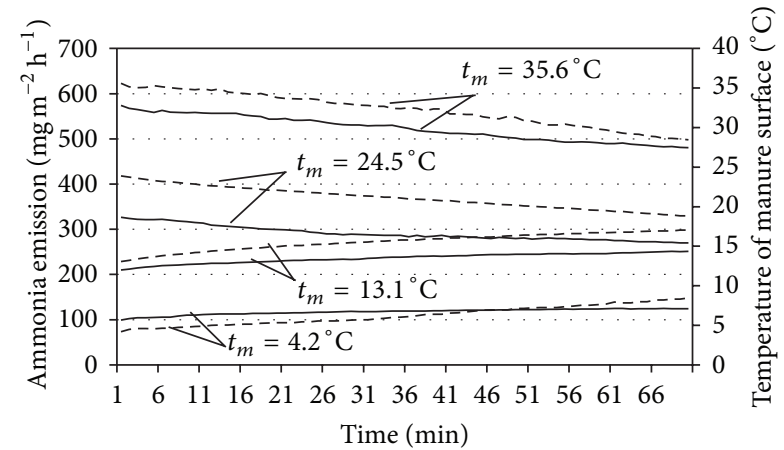

Figure 3: Ammonia emission (solid line) intensity from cattle manure at changing surface temperature (dashed line), $t_{m}$ : manure inner temperature.

\subsection{Modelling of Ammonia Emission under Changing Temper-} ature in the Laboratory Test Bench. As fluctuating temperature transformed air circulation, the determination of the effect of barn temperature on ammonia emission was rather cumbersome. For that reason, the impact of the temperature on ammonia emissions from manure was assessed in the laboratory test bench (Figure 1). The potential impact of air and manure surface temperature as well as temperature gradient of manure layers on ammonia emission intensity was determined by modelling temperature in cowsheds during different seasons. Dry matter contents in fresh manure of $11.84 \pm 0.12 \%$ and $8.62 \pm 0.09 \%$ were recorded of the first and second test, respectively. It was found out that manure temperature affected ammonia emission (Figure 3 ). The manure surface temperatures and ammonia emission intensity is changing towards trend. Emissions were recorded under the two temperature conditions: (1) a higher-temperature inflow which warmed the manure thus increasing ammonia emission and (2) a lower-temperature inflow temperature which was lower if compared to the temperature of manure. Ammonia emission significantly increased at the higher temperatures of layer the manure. $\mathrm{NH}_{3}$ emissions of $323 \pm$ $2.8 \mathrm{mg} \mathrm{m}^{-2} \mathrm{~h}^{-1}$ and $565 \pm 5.9 \mathrm{mg} \mathrm{m}^{-2} \mathrm{~h}^{-1}$ were recorded at $24.5 \pm 0.39^{\circ} \mathrm{C}$ and $35.6^{\circ} \mathrm{C}$ manure temperatures, respectively.

Ammonia emission increased almost sixfold, while manure temperature increased from $4.2^{\circ} \mathrm{C}$ up to $35.6^{\circ} \mathrm{C}$; that is, the temperature increase of $1^{\circ} \mathrm{C}$ increased the ammonia emission by $14.7 \mathrm{mg} \mathrm{m}^{-2} \mathrm{~h}^{-1}$ on average. In addition, this is equivalent to $74.09 \mathrm{~g} \mathrm{~m}^{-2}$ per indoor period (210 day) or some $259 \mathrm{~g}$ per cow space.

When inflow temperature was lower than that of manure, the manure was being cooled, temperature falling of its surface, leading to reduction in ammonia emissions. $\mathrm{NH}_{3}$

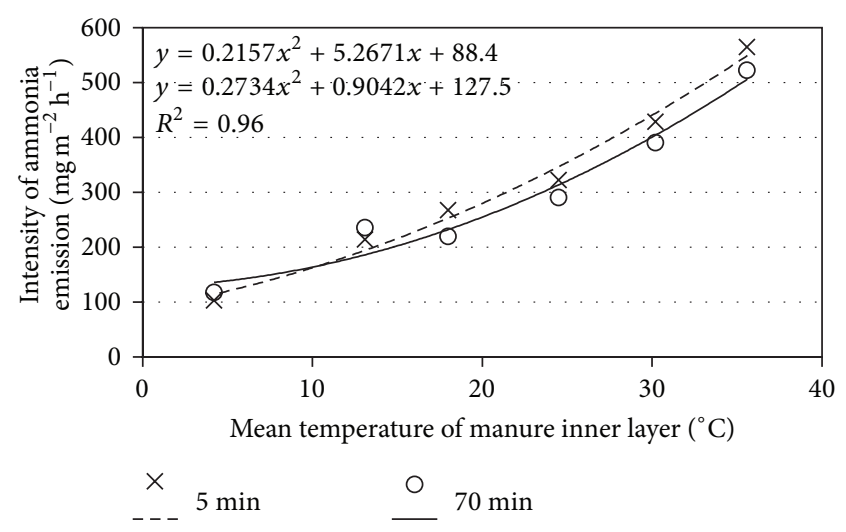

FIGURE 4: Mean intensity of ammonia emission from fresh cattle manure during 5 and $70 \mathrm{~min}$ in against temperature of the inner layer.

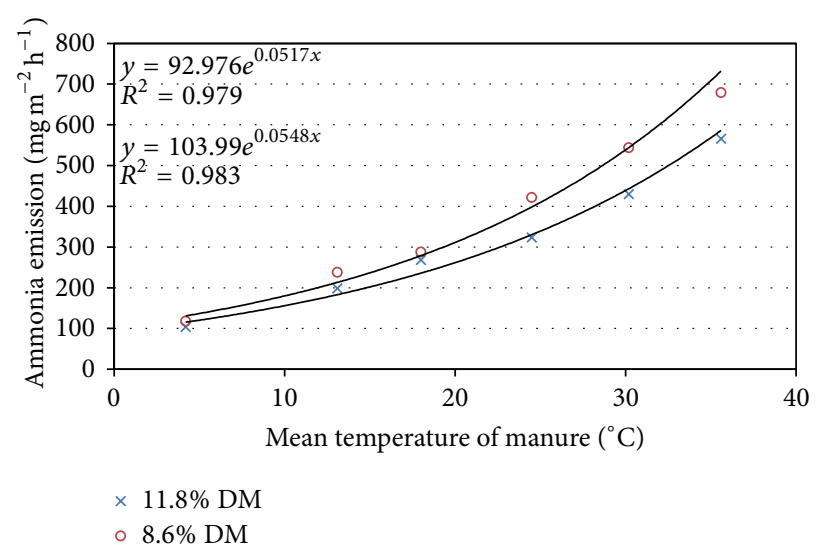

FIGURE 5: Intensity of ammonia emission from cattle manure of different consistency (DM) in dependence on its inner temperature.

emission $\left(103 \pm 2.4 \mathrm{mg} \mathrm{m}^{-2} \mathrm{~h}^{-1}\right.$ and $214 \pm 3.2 \mathrm{mg} \mathrm{m}^{-2} \mathrm{~h}^{-1}$ resp.) was observed only at manure temperatures of $4.2 \pm$ $0.12^{\circ} \mathrm{C}$ and $13.1 \pm 0.29^{\circ} \mathrm{C}$ which were lower than that of inflow air. The impact of temperature on the emission of ammonia at temperatures of $4^{\circ} \mathrm{C}$ to $36^{\circ} \mathrm{C}$ is considerably different; therefore it is appropriate to analyse these processes separately.

Ammonia emission increased exponentially with the increasing manure temperature (Figure 4 ). This dependence remained similar within both short $(5 \mathrm{~min})$ and longer (70 $\mathrm{min})$ periods. The stronger impact of manure temperature on ammonia emission intensity was observed in a short period as well as at higher temperatures. Indeed, the increase in manure temperature of $1^{\circ} \mathrm{C}$ causes the ammonia emission to increase by $7.3 \mathrm{mg}\left(\mathrm{m}^{2} \mathrm{~h}\right)^{-1}, 10.5 \mathrm{mg}\left(\mathrm{m}^{2} \mathrm{~h}\right)^{-1}$, and $17.4 \mathrm{mg}$ $\left(\mathrm{m}^{2} \mathrm{~h}\right)^{-1}$ at $10-20^{\circ} \mathrm{C}, 20-30^{\circ} \mathrm{C}$, and above $20^{\circ} \mathrm{C}$ temperatures, respectively. Subsequently, the temperature rise above $20^{\circ} \mathrm{C}$ must be avoided.

Analysis of smoother manure of less dry matter content $(8.62 \% \pm 0.09 \%)$ revealed similar correlations with temperature $(r=0.9$; Figure 5). Ammonia was dispensed more intensively from smoother manure, with increasing emission gains at the higher temperatures. 


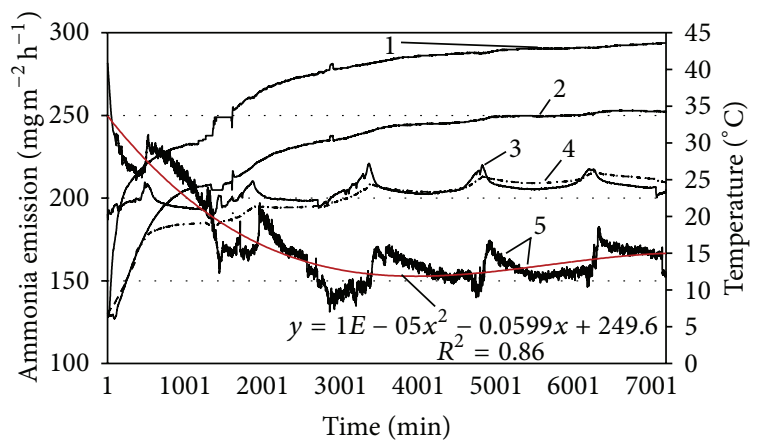

FIGURE 6: Impact of air and manure temperature on the intensity of ammonia emission from cattle manure. 1: manure temperature of the bottom layer; 2 : manure temperature in the middle layer; 3 : manure surface temperature; 4: air temperature; 5: ammonia emission.

In order to analyse manure temperature's impact on ammonia emission in a more detailed way, the manure was heated from the bottom up to $45^{\circ} \mathrm{C}$. The manure temperature rose from $6.1^{\circ} \mathrm{C}$ to $43.6^{\circ} \mathrm{C}$ in the bottom layer, while only to $24.6^{\circ} \mathrm{C}$ in manure surface during the testing period (Figure 6). Intensity of ammonia emission was rather volatile one: it has decreased from $285 \mathrm{mg} \mathrm{m}^{-2} \mathrm{~h}^{-1}$ down to $130 \mathrm{mg}$ $\mathrm{m}^{-2} \mathrm{~h}^{-1}$ during the 50 hours of research and then started to increase as a result of the rising temperature of the manure surface. What the curves of ammonia emission intensity and manure temperature in various layers do indicates that relation between ammonia emission and manure temperature remained rather arbitrary.

Ammonia emission is mainly determined by variations in the temperatures of air and manure surface. Increases in the temperature of the airflow by several degrees centigraded render increase in the temperature of the manure surface and, subsequently, increase in ammonia emission. The analysis of ammonia emission from manure can be analyzed in terms of the short and long periods. Analysis of the processes which occurred during the first $60 \mathrm{~min}$ (Figure 7) indicated that the heat source at the bottom of manure layer did not affect the manure surface temperature, as the temperature did not increase in the inner layer of manure. Indeed, the ammonia emission decreased by some $13 \%$, though temperature rose by only $1.1^{\circ} \mathrm{C}$ in manure surface during the first $60 \mathrm{~min}$.

Nonetheless, the observed values of the ammonia emission were different from those reported in other researches $[10,21,22]$. These differences might have been caused by divergent tests conditions and chemical composition of manure. Anyway, the determined temperature impact on ammonia emissions from manure is adequate to the results obtained in many researches $[13,17,20,23,25]$. Therefore the obtained relationships provided possibilities to analyse and evaluate the processes of ammonia emissions from manure amidst the varying ambient temperature: inner and surface manure temperatures as well as air temperature. Hence, temperature inside the manure remained an important factor as long as it affected both the surface temperature of manure and underlying processes of the manure surface, for example, drying and crust formation. It was found out that the

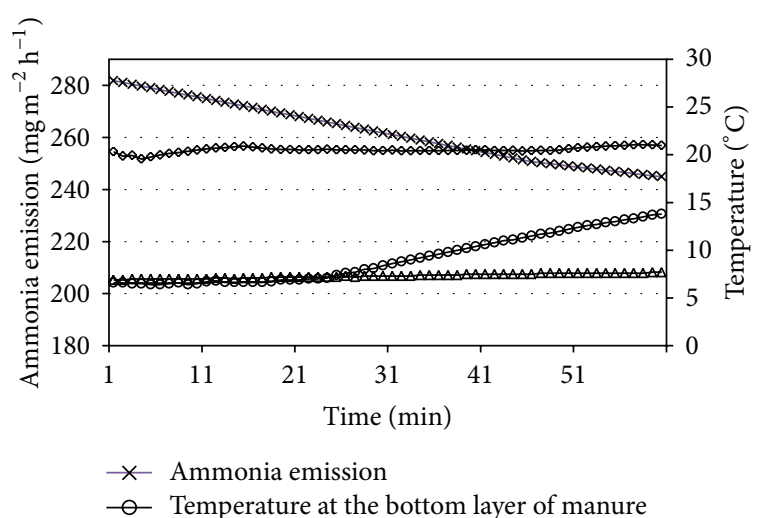

FIGURE 7: Ammonia emission intensity in relation with temperature variation of air and manure.

intensity of these processes generally depends on the difference between the air and manure temperatures. Ammonia emissions from manure can be considerably reduced by controlling the temperature of the air and manure surface. This is explained by the fact that the manure surface's temperature has a significant effect on activity of aerobic ammonification bacteria [26].

\section{Conclusion}

Air temperature in cowsheds varied within a wide range of $15^{\circ} \mathrm{C}$ to $30^{\circ} \mathrm{C}$ during different seasons of the year. Therefore, volatile conditions for ammonification bacteria activity prevailed and thus affected ammonia emissions from manure. The following two issues remain essential in terms of reduction of ammonia emissions from the livestock buildings: First, the optimal regulation of the air temperature in cowshed, especially at high temperatures. Second, the management of the airflow preventing the warm ambient air from blowing directly into the manure. Reduction of the average annual air temperature by $1^{\circ} \mathrm{C}$ in cowshed declined the annual ammonia emissions by some $5.0 \%$.

The trials carried out in the laboratory test bench revealed that the key factor inducing ammonia emissions is temperature of the manure surface and the ambient temperature, which, indeed, directly affected the manure surface's temperature. With increasing manure temperature, ammonia emission increased in exponential way. Thus, the latter's effect was greater at higher temperatures. Specifically, increase in the manure temperature from $4^{\circ} \mathrm{C}$ to $30^{\circ} \mathrm{C}$ caused growth in ammonia emission from $102 \mathrm{mg} \mathrm{m}^{-2} \mathrm{~h}^{-1}$ to $430 \mathrm{mg} \mathrm{m}^{-2} \mathrm{~h}^{-1}$, namely, about 4 times. All in all, the temperatures above $20^{\circ} \mathrm{C}$ should be avoided, for temperature rise by $1^{\circ} \mathrm{C}$ in this region caused increase of ammonia emission of more than $17 \mathrm{mg} \mathrm{m}^{-2} \mathrm{~h}^{-1}$. The analysis of emission processes from the manure has to involve assessment of air and manure surface's temperatures, as well as the temperature's gradient. The inner temperature of the manure layer remains important as long as it affects both its surface temperature and the underlying processes in manure surface, for example, drying and crust formation. 


\section{References}

[1] J. Webb, H. Menzi, B. F. Pain et al., "Managing ammonia emissions from livestock production in Europe," Environmental Pollution, vol. 135, no. 3, pp. 399-406, 2005.

[2] S. G. Sommer, G. Q. Zhang, A. Bannink et al., "Algorithms determining ammonia emission from buildings housing cattle and pigs and from Mmanure stores," Advances in Agronomy, vol. 89, pp. 261-335, 2006.

[3] P. Epinatjeff, “Aussenklimastalle fur Milchvien," Landt, vol. 52, pp. 313-316, 1997.

[4] K. A. Janni and D. M. Alenn, "Thermal environmental conditions in curtain-sided naturaly ventilated dairy freestall barns," in Livestock Environment, vol. 6, pp. 367-376, ASAE 701PO2001, Kentucky, Ky, USA, 2001.

[5] R. Hilty, R. Kaufman, and L. Caenegem, "Building for cattle husbandry," in Yearbook of Agricultural Engineering, H. J. Mathies and F. Meier, Eds., vol. 14, pp. 163-170, VDMA Landtechnik, Burgdorf, Switzerland, 2003.

[6] M. M. Lucenko and D. V. Salyga, "The estimation of functioning of new volumetric-planning and technological decisions of easily-sectional cowsheds in the conditions of Ukraine," in New Development of Technologies and Technical Means In Dairy, pp. 140-146, Gomel, Minsk, Belarus, 2006.

[7] G. Brose, Emission von klimarelevanten Gasen, ammoniak und Geruch aus einem milchviehstall mit schwerkraftlüftung [M.S. thesis], Universität Hohenheim, Stuttgart, Germany, 2000.

[8] B. Eurich-Menden, Ammoniak-Emissionen in der Landwirtschaft minDern, KTBL, Hannover, Germany, 1993.

[9] G. L. Velthof, C. van Bruggen, C. M. Groenestein, B. J. de Haan, M. W. Hoogeveen, and J. F. M. Huijsmans, "A model for inventory of ammonia emissions from agriculture in the Netherlands," Atmospheric Environment, vol. 46, pp. 248-255, 2012.

[10] T. Cassel, L. Ashbaugh, R. Flocchini, and D. Meyer, "Ammonia flux from open-lot dairies: development of measurement methodology and emission factors," Journal of the Air and Waste Management Association, vol. 55, no. 6, pp. 816-825, 2005.

[11] A. J. Heber, J. Ni, T. T. Lim et al., "Quality assured measurements of animal building emissions: gas concentrations," Journal of the Air and Waste Management Association, vol. 56, no. 10, pp. 14721483, 2006.

[12] H. G. J. Snell, F. Seipelt, and H. F. A. Van Den Weghe, "Ventilation rates and gaseous emissions from naturally ventilated dairy houses," Biosystems Engineering, vol. 86, no. 1, pp. 67-73, 2003.

[13] F. K. Teye, Microclimate and gas emissions in dairy buildings: instrumentation, theory and measurements [Ph.D. thesis], University of Helsinki, Helsinki, Finland, 2008.

[14] E. Vranken, S. Claes, J. Hendriks, P. Darius, and D. Berckmans, "Intermittent measurements to determine ammonia emissions from livestock buildings," Biosystems Engineering, vol. 88, no. 3, pp. 351-358, 2004.

[15] J. Dekock, E. Vranken, E. Gallmann, E. Hartung, and D. Berckmans, "Optimisation and validation of the intermittent measurement method to determine ammonia emissions from livestock buildings," Biosystems Engineering, vol. 104, no. 3, pp. 396-403, 2009.

[16] C. K. Saha, G. Zhang, and J. Ni, "Airflow and concentration characterisation and ammonia mass transfer modelling in wind tunnel studies," Biosystems Engineering, vol. 107, no. 4, pp. 328340, 2010.
[17] L. Rong, P. V. Nielsen, and G. Zhang, "Effects of airflow and liquid temperature on ammonia mass transfer above an emission surface: experimental study on emission rate," Bioresource Technology, vol. 100, no. 20, pp. 4654-4661, 2009.

[18] M. J. Aguerre, M. A. Wattiaux, and J. M. Powell, "Emissions of ammonia, nitrous oxide, methane, and carbon dioxide during storage of dairy cow manure as affected by dietary forage-toconcentrate ratio and crust formation," Journal of Dairy Science, vol. 95, no. 12, pp. 7409-7416, 2012.

[19] S. A. Burgos, N. M. Embertson, Y. Zhao, F. M. Mitloehner, E. J. DePeters, and J. G. Fadel, "Prediction of ammonia emission from dairy cattle manure based on milk urea nitrogen: relation of milk urea nitrogen to ammonia emissions," Journal of Dairy Science, vol. 93, no. 6, pp. 2377-2386, 2010.

[20] G. Zhang, J. S. Strøm, B. Li et al., "Emission of ammonia and other contaminant gases from naturally ventilated dairy cattle buildings," Biosystems Engineering, vol. 92, no. 3, pp. 355-364, 2005.

[21] B. Van der Stelt, E. J. M. Temminghoff, P. C. J. Van Vliet, and W. H. Van Riemsdijk, "Volatilization of ammonia from manure as affected by manure additives, temperature and mixing," Bioresource Technology, vol. 98, no. 18, pp. 3449-3455, 2007.

[22] N. M. Ngwabie, Gas emissions from dairy cow and fattening pig buildings: effects of animal parameters, climatic factors and manure management on methane and ammonia emissions [Ph.D. thesis], Swedish University of Agricultural Sciences, Uppsala, Sweden, 2011.

[23] J. Pereira, T. H. Misselbrook, D. R. Chadwick, J. Coutinho, and H. Trindade, "Effects of temperature and dairy cattle excreta characteristics on potential ammonia and greenhouse gas emissions from housing: a laboratory study," Biosystems Engineering, vol. 112, no. 2, pp. 138-150, 2012.

[24] N. W. M. Ogink, J. Mosquera, S. Calvet, and G. Zhang, "Methods for measuring gas emissions from naturally ventilated livestock buildings: developments over the last decade and perspectives for improvement," Biosystems Engineering, vol. 116, no. 3, pp. 297-308, 2013.

[25] C. Wang, B. Li, G. Zhang, H. B. Rom, and J. S. Strøm, "Model estimation and measurement of ammonia emission from naturally ventilated dairy cattle buildings with slatted floor designs," Journal of the Air and Waste Management Association, vol. 56, no. 9, pp. 1252-1259, 2006.

[26] J. W. B. Moir, Ed., Nitrogen Cycling in Bacteria: Molecular Analysis, Caister Academic Press, Norfolk, UK, 2011. 

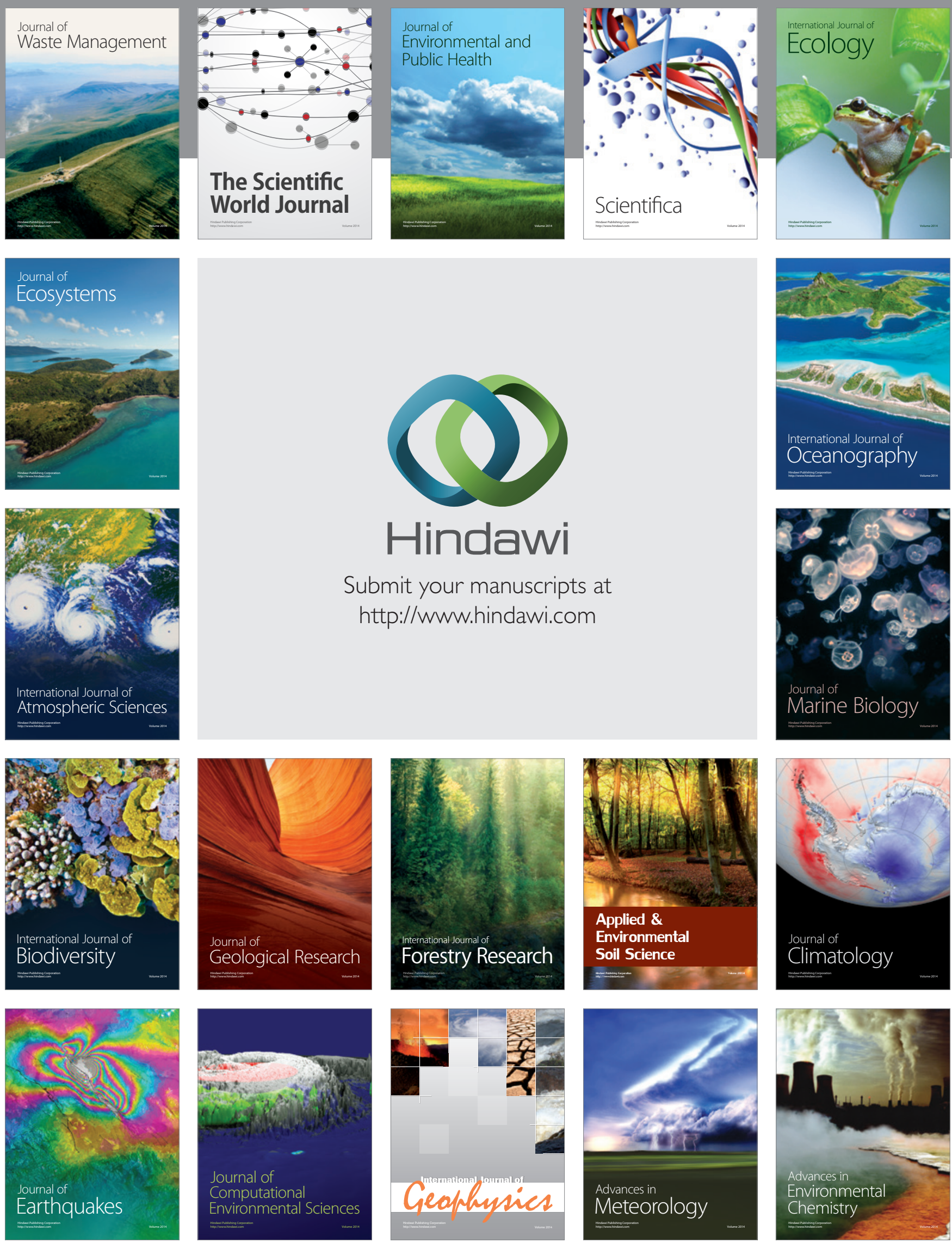